\title{
PENGARUH KINERJA BAURAN PEMASARAN JASA TERHADAP LOYALITAS NASABAH PENABUNG (Suatu Survai di Bank Central Asia Cabang Soekarno-Hatta Bandung)
}

\author{
Bob Foster
}

\begin{abstract}
Abstrak
Ekonomi sektoral pada tahun 2002 secara umum diperkirakan akan mengalami penurunan pertumbuhan ukuran pasar. Pertumbuhan di sektor perbankan yang pada tahun 2001 mencapai 34,46\% diperkirakan akan mengalami penurunan di tahun 2002 menjadi $12,18 \%$. Sementara itu jumlah tabungan nasabah di BCA Soekarno-Hatta Bandung mengalami penurunan dari 111.315 nasabah pada tahun 2000 menjadi 97.794 nasabah pada tahun 2001. Tujuan penelitian ini ialah untuk mengetahui tingkat kepentingan nasabah terhadap bauran pemasaran jasa tabungan dan kinerja bauran pemasaran jasa perbankan pada BCA; tingkat loyalitas nasabah terhadap produk tabungan BCA; dan sejauh mana kinerja bauran pemasaran jasa bank berpengaruh terhadap loyalitas nasabah.

Jenis penelitian ini adalah deskriptif dan verifikatif dengan metode penelitian descriptive survey dan explanatory survey. Data diperoleh melalui kuesioner, wawancara, dan observasi di lapangan. Hasil pengumpulan data dengan sumber data primer diperoleh dari jumlah sampel sebesar 116 responden. Metode analisis yang digunakan adalah analisis jalur (path analysis).

Berdasarkan hasil penelitian di lapangan diketahui bahwa tingkat kepentingan unsur-unsur bauran pemasaran jasa rata-rata penting dan sangat penting bagi nasabah, sementara kinerja bauran pemasaran jasa BCA Soekarno-Hatta Bandung mendapatkan penilaian yang berkisar antara cukup baik sampai dengan sangat baik dari para nasabahnya. Tingkat kepentingan nasabah terhadap bauran pemasaran jasa rata-rata lebih tinggi dari kinerja bauran pemasaran BCA sehingga rata-rata kinerja masih di bawah garis optimum performance. Sedangkan tingkat loyalitas nasabah mayoritas berada pada level clients, advocates, dan partners. Berdaasrkan hasil pengujian statistik dengan menggunakan analisis jalur diketahui bahwa pengaruh bauran pemasaran BCA Soekarno-Hatta Bandung terhadap loyalitas nasabah adalah tinggi. Pengaruh kinerja bauran pemasaran jasa terhadap loyalitas nasabah BCA Soekarno-Hatta Bandung adalah sebesar 78,87\%. Selanjutnya pengaruh program bauran pemasaran tradisional terhadap loyalitas nasabah BCA adalah sebesar $39,69 \%$, yang berarti lebih dominan daripada pengaruh program bauran pemasaran non-tradisional yang besarnya $39,64 \%$.
\end{abstract}

\section{Kata Kunci : Kinerja Bauran Pemasaran Jasa dan Loyalitas Nasabah}

\section{PENDAHULUAN}

\subsection{Latar Belakang}

Dewasa ini sektor perbankan tetap giat menjaring dana masyarakat dengan menawarkan berbagai pemikat mulai dari pemberian hadiah dalam hitungan milyaran rupiah sampai dengan penawaran kemudahan pengambilannya. Padahal, perbankan nasional, masih belum mampu melakukan ekspansi kredit dalam jumlah yang signifikan. Penyaluran kredit yang masih sulit dalam kondisi dana melimpah ini diperkirakan Biro Riset Info Bank masih terus berlangsung hingga paling cepat tahun 2004, bahkan sampai tahun 2005. Menurut penelitian Mc Kinsey \& Co, (2000:4) terhadap responden consumer banking di Indonesia, meskipun mereka cukup loyal dengan banknya terutama bank papan atas seperti BCA, BNI, Bank Mandiri, Bank Bali, Bank Niaga, CitiBank dan Standard Chartered, tapi mereka tetap mau pindah ke bank lain jika bank lain dapat memberikan pelayanan yang sesuai dengan keinginannya. Hal lain yang diperoleh dari penelitian tersebut adalah semakin tinggi tingkat pendapatan seseorang, ternyata makin potensial menjadi nasabah yang tidak loyal.

Hasil penelitian lain dari Mc Kinsey (2000:20) adalah membuat tujuh segmentasi nasabah perbankan dengan responden sebanyak $4088 \mathrm{di}$ 


\section{StrategiC}

Asia, termasuk Indonesia. Adapun ketujuh segmen

- TUSUH SEGNENTASI NASABAH DIASIA

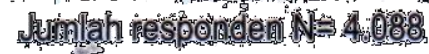

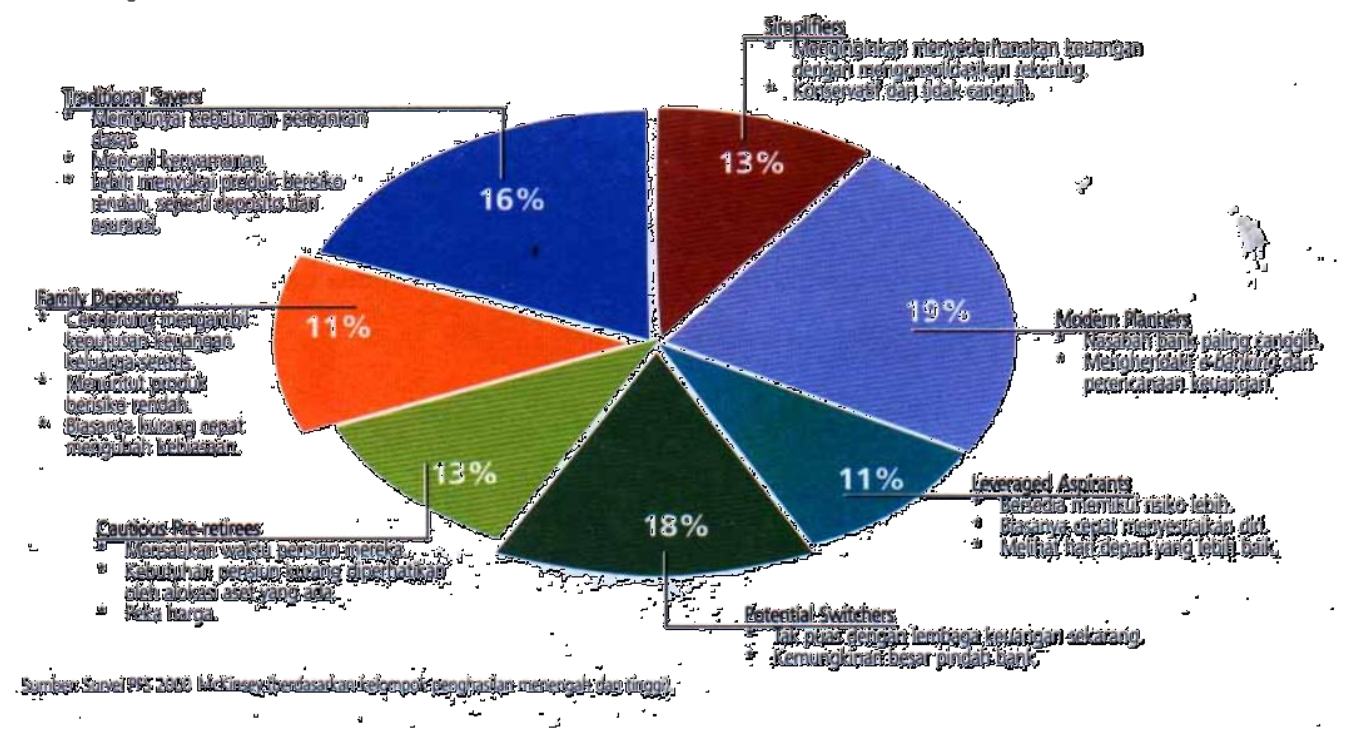

tersebut dapat digambarkan pada Gambar 1.

Gambar 1

Tujuh Segmentasi Nasabah Di Asia

Sementara itu, timbul kesan bagi para nasabah BCA Cabang Soekarno-Hatta Bandung bahwa BCA menyikapi keberhasilannya dalam produk tabungan dengan cara yang melawan arus. BCA menaikkan setoran minimal tabungan BCA dari Rp50.000,00 menjadi Rp500.000,00 yang diberlakukan sejak 9 Oktober 2000. Hal ini dirasa mengganjal konsumen. Kemudian sejak 15 Januari 2002 para nasabah tidak diperkenankan lagi menarik dana Tahapan BCA lebih besar dari Rp25.000.000,00 di luar kantor BCA tempat Tahapan tersebut terdaftar. Padahal, selama ini BCA selalu memberikan kemudahan kepada nasabahnya. Hal ini mengindikasikan adanya persepsi nasabah mengenai penurunan kinerja bauran pemasaran BCA yang dapat mengakibatkan penurunan loyalitas nasabah. Apalagi jumlah nasabah tabungan di BCA Soekarno-Hatta Bandung mengalami penurunan dari 111.315 nasabah pada tahun 2000 menjadi 97.794 nasabah pada tahun 2001.

Untuk mencapai kepuasan dan loyalitas konsumen, perusahaan dapat menerapkan strategi pemasaran yang baik. Salah satu strategi pemasaran yang dipakai oleh perusahaan adalah marketing mix atau bauran pemasaran. Menurut Bernard $\mathrm{H}$. Booms dan Mary Jo Bitner bauran pemasaran jasa terdiri dari product, price, place, promotion, people, physical evidence, dan process, seperti yang dikemukakan oleh Roland T. Rust, Anthony J. Zahorik dan Timothy L. Keiningham (1996:10).

Melihat pentingnya bauran pemasaran untuk memikat konsumen agar konsumen puas dan loyal, maka bisa diambil kesimpulan bahwa kepuasan dan loyalitas konsumen berhubungan erat dengan bauran pemasaran. Bila bauran pemasaran yang dilakukan oleh perusahaan kurang sesuai dengan keinginan konsumen maka perusahaan tersebut akan ditinggalkan para konsumennya dan mereka memilih perusahaan lain yang memiliki nilai lebih dalam bauran pemasaran. Akan tetapi, bila bauran pemasaran yang dilakukan perusahaan sesuai dengan keinginan konsumen maka kepuasan konsumen akan tercapai yang pada akhirnya konsumen tersebut menjadi loyal.

Berdasarkan latar belakang tersebut maka penelitian ini menguji bagaimana "Pengaruh Bauran Pemasaran Jasa Terhadap Loyalitas Nasabah 
Penabung di Bank Central Asia Cabang Soekarno-Hatta Bandung." Sedangkan segmen nasabah yang diteliti adalah nasabah penabung di Bank Central Asia Cabang Soekarno-Hatta Bandung.

\subsection{Identifikasi Masalah}

Permasalahan yang akan dianalisis dalam penelitian ini adalah sebagai berikut.

1. Bagaimana tingkat kepentingan bauran pemasaran jasa tabungan bagi nasabah dan kinerja bauran pemasaran jasa bank yang dirasakan oleh nasabah pada Bank Central Asia Cabang Soekarno-Hatta Bandung.

2. Bagaimana kondisi loyalitas nasabah Bank Central Asia Cabang Soekarno-Hatta Bandung dewasa ini.

3. Sejauhmana pengaruh kinerja bauran pemasaran jasa terhadap loyalitas nasabah tabungan Bank Central Asia Cabang Soekarno-Hatta Bandung.

\subsection{Tujuan Penelitian}

Tujuan penelitian ini adalah untuk mengetahui:

1. Tingkat kepentingan bauran pemasaran jasa tabungan bagi nasabah dan kinerja bauran, pemasaran jasa bank yang dirasakan oleh nasabah pada BCA Cabang Soekarno-Hatta Bandung.

2. Kondisi loyalitas nasabah BCA Cabang Soekarno-Hatta Bandung dewasa ini.

3. Sejauhmana pengaruh kinerja bauran pemasaran jasa yang dilaksanakan oleh BCA Cabang Soekarno-Hatta Bandung terhadap loyalitas nasabah tabungan.

\subsection{Kegunaan Penelitian}

Hasil penelitian yang diperoleh diharapkan dapat berguna dalam hal berikut.

1. Secara praktis, diharapkan dapat sebagai bahan pertimbangan dan sumbangan pemikiran yang bermanfaat bagi pihak Bank Central Asia Cabang Soekarno-Hatta Bandung khususnya dan pihak perbankan umumnya untuk lebih meningkatkan kualitas kebijaksanaan dalam hal bauran pemasaran jasa di masa yang akan datang.

2. Secara toritis, berguna dalam pengembangan ilmu manajemen, terutama manajemen pemasaran dan lebih khusus lagi manajemen pemasaran jasa perbankan dalam kaitannya dengan loyalitas pelanggan.

\section{KERANGKA PEMIKIRAN DAN HIPOTESIS}

\subsection{Kerangka Pemikiran}

Kotler (2000: 92) mengemukakan bahwa bauran pemasaran (marketing mix) adalah sekumpulan alat pemasaran yang dapat digunakan oleh perusahaan untuk meraih tujuan pemasaran. Sementara Zeithaml dan Bitner (2000:18) mengemukakan bahwa bauran pemasaran merupakan unsur-unsur yang dapat digunakan oleh perusahaan untuk berkomunikasi dan memuaskan konsumen.

Selanjutnya Zeithaml dan Bitner juga mengemukakan konsep bauran pemasaran tradisional (traditional marketing mix) yang terdiri dari 4P yaitu product, price, place (distribution), dan promotion. Sementara untuk pemasaran jasa (the service marketing mix) terdapat unsur bauran pemasaran yang diperluas (expanded marketing mix for service) yaitu 4P ditambah people, physical evidence, dan process. Masing-masing dari tujuh unsur bauran pemasaran tersebut, saling berhubungan dan tergantung satu dengan yang lain (Zeithaml, 2000 : 18 - 20).

Penambahan unsur bauran pemasaran jasa dilakukan antara lain karena jasa memiliki karakteristik yang berbeda dengan produk yaitu: intangibility (tidak berwujud), inseparability (tidak dapat dipisahkan), variability (beraneka ragam), dan perishability (mudah lenyap), sehingga penggunaan bauran pemasaran produk 4P (product, price, place, dan promotion) saja kurang memadai. Seperti yang juga dikemukakan oleh Booms dan Bitner dalam Rust, Zahorik, dan Keiningham (1996:10), bahwa bauran pemasaran jasa terdiri dari 7P yaitu: product, price, place, promotion, people, physical evidence, dan process.

Kepuasan konsumen dapat dilihat dari sejauh mana harapan konsumen dapat dipenuhi oleh kinerja aktual perusahaan. Menurut Kotler dan Armstrong dalam Tjiptono (1998:160), apabila pelanggan merasa puas terhadap bauran pemasaran jasa, maka pelanggan akan melakukan pemakaian jasa ulang, bahkan lebih jauh lagi, mereka akan melakukan promosi dari mulut ke mulut kepada rekan, saudara, atau kenalan terdekatnya agar sama-sama menggunakan pelayanan jasa untuk berbagai keperluan di perusahaan yang sama. Dengan perkataan lain pelanggan tersebut akan menjadi loyal. 
Berdasarkan uraian pada kerangka pemikiran penelitian, maka paradigma pengaruh kinerja bauran pemasaran terhadap loyalitas nasabah dapat diungkapkan pada Gambar 2 di halaman selanjutnya.

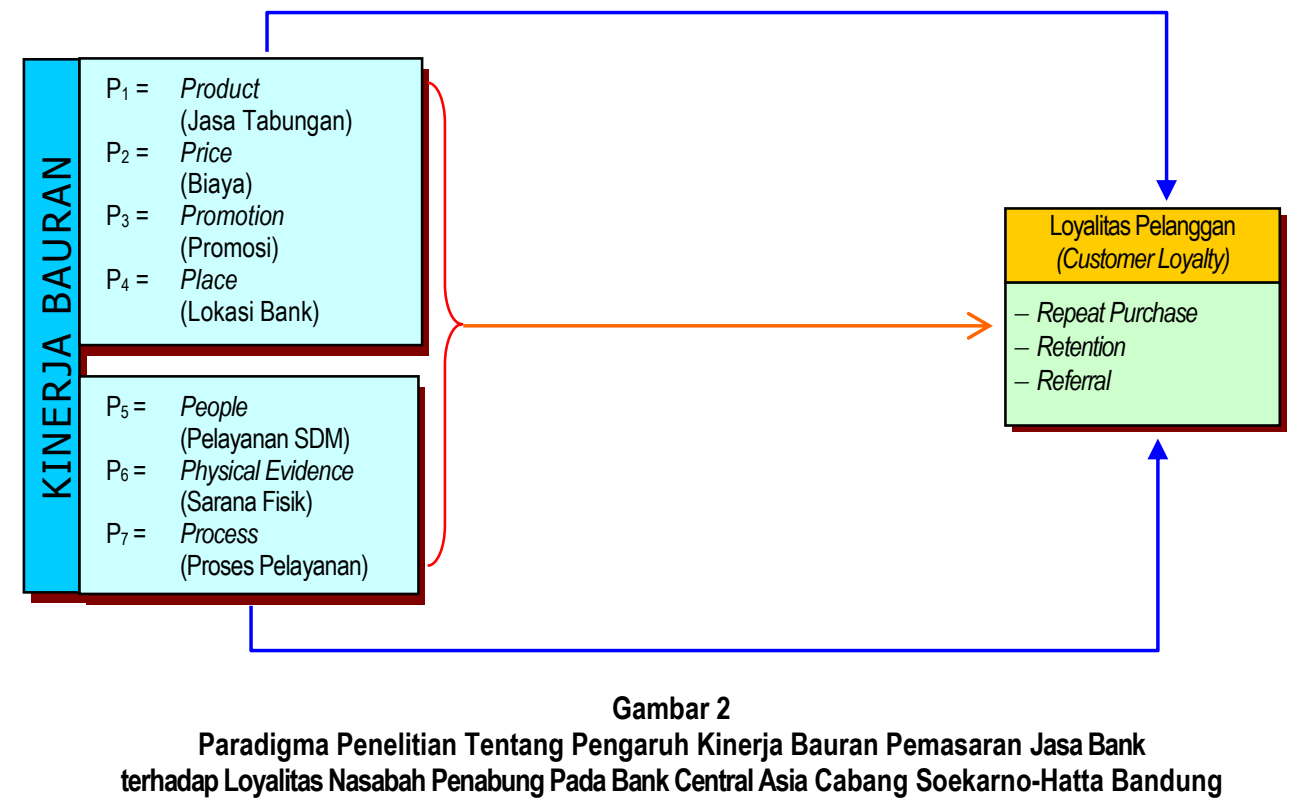

\subsection{Hipotesis Penelitian}

Berdasarkan uraian pada kerangka pemikiran penelitian maka hipotesis yang dikemukakan pada penelitian ini adalah:

I. Kinerja bauran pemasaran jasa berpengaruh terhadap loyalitas nasabah BCA Cabang Soekarno-Hatta Bandung.

II. Kinerja bauran pemasaran tradisional dan kinerja bauran pemasaran non-tradisional secara simultan berpengaruh terhadap loyalitas nasabah BCA Cabang Soekarno-Hatta Bandung.

II.1 Kinerja bauran pemasaran tradisional yang terdiri dari product, price, place, dan promotion berpengaruh terhadap loyalitas nasabah BCA.

II.2 Kinerja bauran pemasaran non-tradisional yang terdiri dari people, physical evidence, dan process berpengaruh terhadap loyalitas nasabah BCA.

III. Kinerja unsur-unsur bauran pemasaran jasa bank secara simultan berpengaruh terhadap loyalitas nasabah BCA Cabang SoekarnoHatta Bandung.
III.1 Kinerja produk jasa bank berpengaruh terhadap loyalitas nasabah BCA Cabang Soekarno - Hatta Bandung.

III.2 Kinerja biaya bank berpengaruh terhadap loyalitas nasabah BCA Cabang Soekarno - Hatta Bandung.

III.3 Kinerja lokasi/tempat pelayanan jasa bank berpengaruh terhadap loyalitas nasabah BCA Cabang Soekarno - Hatta Bandung.

III.4 Kinerja promosi jasa bank berpengaruh terhadap loyalitas nasabah BCA Cabang Soekarno - Hatta Bandung.

III.5 Kinerja pelayanan petugas jasa bank berpengaruh terhadap loyalitas nasabah BCA Cabang Soekarno - Hatta Bandung.

III.6 Kinerja bukti fisik jasa bank berpengaruh terhadap loyalitas nasabah BCA Cabang Soekarno - Hatta Bandung.

III.7 Kinerja proses jasa bank berpengaruh terhadap loyalitas nasabah BCA Cabang Soekarno - Hatta Bandung. 


\section{OBJEK DAN METODE PENELITIAN}

\subsection{Objek Penelitian}

Objek penelitian sebagai variabel independen (variabel bebas) adalah kinerja bauran pemasaran jasa Bank Central Asia Cabang Soekarno-Hatta Bandung yang terdiri dari tujuh buah sub-variabel berikut. Pertama, jasa. Kedua, biaya meliputi kewajaran tarif. Ketiga, lokasi/tempat pelayanan terdiri atas ketepatan tempat pelayanan dan jumlah tempat pelayanan. Keempat, promosi meliputi program periklanan, kegiatan personal selling, kegiatan promosi penjualan, dan kegiatan publikasi. Kelima, petugas meliputi penampilan petugas, keramahan petugas, dan kecepatan pelayanan. Keenam, bukti fisik terdiri dari kondisi kantor pelayanan. Ketujuh, proses pelayanan yang meliputi proses pelayanan menjadi nasabah, proses penyetoran dan proses penarikan tabungan. Ketujuh sub-variabel tersebut dikelompokkan menjadi bauran pemasaran tradisional dan bauran pemasaran non-tradisional. Bauran pemasaran tradisional terdiri dari jasa, biaya, lokasi, dan promosi sedangkan bauran pemasaran non-tradisional terdiri dari petugas, bukti fisik, dan proses pelayanan.

Objek penelitian yang merupakan variabel dependen (varibel tak bebas) adalah loyalitas nasabah. Ukuran loyalitas nasabah dalam penelitian ini adalah pembelian ulang (repeat), pembelian di luar lini produk jasa, mengajak orang lain (referral), dan tidak mudah terpengaruh oleh tarikan persaingan produk sejenis lainnya (retention).

Konsumen yang dijadikan sebagai responden adalah para nasabah tabungan BCA Cabang Soekarno - Hatta Bandung. Penelitian ini dilakukan mulai bulan Januari hingga bulan Maret 2002. Dari objek penelitian ini dapat dianalisis hal-hal berikut. Pertama, kinerja bauran pemasaran jasa bank menurut tanggapan nasabah. Kedua, mengukur pengaruh bauran pemasaran jasa bank terhadap loyalitas nasabah BCA Cabang Soekarno - Hatta Bandung.

\subsection{Metode Penelitian}

\subsubsection{Desain Penelitian}

Atas pertimbangan tujuan penelitian, maka penelitian ini bersifat verifikatif dan deskriptif. Penelitian deskriptif adalah penelitian yang bertujuan untuk memperoleh deskripsi tentang ciriciri variabel (kinerja bauran pemasaran jasa bank). Sifat penelitian verifikatif pada dasarnya ingin menguji kebenaran dari suatu hipotesis yang dilaksanakan melalui pengumpulan data di lapangan. Dalam penelitian ini akan diuji apakah kinerja bauran pemasaran jasa bank berpengaruh terhadap loyalitas nasabah sehingga tipe penelitian adalah causality.

Mengingat sifat penelitian ini adalah deskriptif dan verifikatif yang dilaksanakan melalui pengumpulan data di lapangan, maka metode penelitian yang digunakan adalah metode descriptive survey dan metode explanatory survey. Informasi dari sebagian populasi (sampel responden) dikumpulkan langsung di tempat kejadian secara empirik, dengan tujuan untuk mengetahui pendapat dari sebagian populasi terhadap objek yang sedang diteliti. Sumber data yang digunakan sebagai unit analysis ada satu (individual) yaitu nasabah tabungan bank. Sedangkan kurun waktu penelitian berada dalam 1 tahun sehingga cakupan waktunya adalah crosssectional sample.

\subsubsection{Operasionalisasi Variabel Penelitian}

Secara lebih rinci, operasionalisasi variabel untuk menjawab identifikasi masalah nomor 1, 2 dan nomor 3 terlihat pada Tabel 1.

Tabel 1

Operasionalisasi Variabel Penelitian

\begin{tabular}{|l|l|l|l|l|}
\hline \multicolumn{1}{|c|}{$\begin{array}{c}\text { Variabel I } \\
\text { Sub-variabel }\end{array}$} & \multicolumn{1}{|c|}{ Konsep Variabel } & \multicolumn{1}{|c|}{ Indikator } & \multicolumn{1}{c|}{ Ukuran } & Skala \\
\hline $\begin{array}{l}\text { Kinerja Bauran } \\
\begin{array}{l}\text { Pemasaran Jasa } \\
(\mathrm{X})\end{array}\end{array}$ & $\begin{array}{l}\text { Suatu konsep yang } \\
\text { menekankan pada pentingnya } \\
\text { kualitas dari segi jasa, biaya } \\
\text { bank, lokasi/tempat pelayanan, } \\
\text { promosi, petugas, sarana fisik, } \\
\text { dan prosedur }\end{array}$ & $\begin{array}{l}\text { Pelaksanaan bauran pema-saran } \\
\text { jasa bank yang meliputi produk, } \\
\text { biaya/bunga bank, lokasi/tempat } \\
\text { pelayanan, promosi, petugas, } \\
\text { sarana fisik, dan prosedur }\end{array}$ & $\begin{array}{l}\text { Tingkat pelaksanaan bauran } \\
\text { pemasaran jasa bank }\end{array}$ & \\
& & & Ordinal \\
\end{tabular}

Pengaruh Kinerja Bauran Pemasaran Jasa terhadap Loyalitas Nasabah Penabung 


\begin{tabular}{|c|c|c|c|c|c|}
\hline \multicolumn{2}{|c|}{$\begin{array}{c}\text { Variabel / } \\
\text { Sub-variabel }\end{array}$} & \multirow{5}{*}{$\begin{array}{l}\text { Konsep Variabel } \\
\text { Segala tindakan atau manfaat } \\
\text { yang dapat ditawarkan oleh } \\
\text { suatu pihak kepada pihak lain } \\
\text { yang pada dasarnya tidak } \\
\text { berwujud dan tidak } \\
\text { mengakibatkan kepemilikan } \\
\text { suatu apapun. } \\
\text { Produksinya dapat dikaitkan } \\
\text { atau tidak dikaitkan pada satu } \\
\text { produk fisik. }\end{array}$} & Indikator & Ukuran & Skala \\
\hline \multirow{16}{*}{$\begin{array}{l}T \\
R \\
A \\
D \\
I \\
S \\
I \\
O \\
N \\
A \\
L \\
\left(X^{\prime}\right)\end{array}$} & \multirow{4}{*}{$\begin{array}{l}\text { Jasa } \\
\text { (Product) } \\
\left(\mathrm{X}_{1}\right)\end{array}$} & & $\begin{array}{l}\text { Kemudahan pendaftaran menjadi } \\
\text { nasabah penabung baru }\end{array}$ & Tingkat kemudahan & Ordinal \\
\hline & & & Penetapan saldo minimal & $\begin{array}{l}\text { Tingkat daya tarik saldo } \\
\text { minimal }\end{array}$ & Ordinal \\
\hline & & & $\begin{array}{l}\text { Kompensasi/bunga yang } \\
\text { ditawarkan }\end{array}$ & $\begin{array}{l}\text { Tingkat daya tarik kompensasi } \\
\text { /bunga yang ditawarkan }\end{array}$ & Ordinal \\
\hline & & & $\begin{array}{l}\text { Keamanan tabungan milik } \\
\text { nasabah }\end{array}$ & Tingkat keamanan tabungan & Ordinal \\
\hline & \multirow{4}{*}{$\begin{array}{l}\text { Biaya (Price) } \\
\left(\mathrm{X}_{2}\right)\end{array}$} & \multirow{4}{*}{$\begin{array}{l}\text { Sejumlah uang yang dibayarkan } \\
\text { nasabah dalam memperoleh } \\
\text { produk hasil perusahaan }\end{array}$} & $\begin{array}{l}\text { Keterjangkauan biaya menjadi } \\
\text { penabung baru }\end{array}$ & Tingkat keterjangkauan biaya & Ordinal \\
\hline & & & $\begin{array}{l}\text { Daya tarik keringanan biaya } \\
\text { fasilitas bank }\end{array}$ & $\begin{array}{l}\text { Tingkat daya tarik keringanan } \\
\text { biaya }\end{array}$ & Ordinal \\
\hline & & & $\begin{array}{l}\text { Keterjangkauan } \\
\text { biaya jasa tabungan }\end{array}$ & Tingkat keterjangkauan biaya & Ordinal \\
\hline & & & $\begin{array}{l}\text { Murahnya biaya pembuatan kartu } \\
\text { ATM }\end{array}$ & Tingkat kemurahan & Ordinal \\
\hline & \multirow{3}{*}{$\begin{array}{l}\text { Lokasi/ } \\
\text { Tempat } \\
\text { (Place) } \\
\left(\mathrm{X}_{3}\right)\end{array}$} & \multirow{3}{*}{$\begin{array}{l}\text { Merupakan perencanaan dan } \\
\text { pelaksanaan program } \\
\text { penyaluran produk melalui } \\
\text { tempat yang tepat }\end{array}$} & $\begin{array}{l}\text { Ketersediaan kantor cabang yang } \\
\text { mudah dicapai }\end{array}$ & $\begin{array}{l}\text { Tingkat ketersediaan kantor } \\
\text { cabang }\end{array}$ & Ordinal \\
\hline & & & Jumlah tempat pelayanan & $\begin{array}{l}\text { Tingkat banyaknya tempat } \\
\text { pelayanan }\end{array}$ & Ordinal \\
\hline & & & Memadainya jumlah ATM & Tingkat memadai & Ordinal \\
\hline & \multirow{5}{*}{$\begin{array}{l}\text { Promosi } \\
\text { (Promotion) } \\
\left(\mathrm{X}_{4}\right)\end{array}$} & \multirow{5}{*}{$\begin{array}{l}\text { Merupakan aktivitas pemasaran } \\
\text { untuk mengkomunikasikan } \\
\text { informasi tentang perusahaan } \\
\text { dan produknya kepada nasabah }\end{array}$} & Pesan iklan yang menarik & Tingkat menarik & Ordinal \\
\hline & & & Daya tarik penjelasan petugas & Tingkat daya tarik & Ordinal \\
\hline & & & Daya tarik sales promotion & Tingkat daya tarik & Ordinal \\
\hline & & & Kegiatan publisitas & Frekuensi publisitas & Ordinal \\
\hline & & & Jumlah variasi media & Tingkat banyaknya & Ordinal \\
\hline \multirow{7}{*}{$\begin{array}{l}\mathrm{N} \\
\mathrm{O} \\
\mathrm{N}\end{array}$} & \multirow{4}{*}{$\begin{array}{l}\text { Orang } \\
\text { (SDM) } \\
\text { (People) } \\
\left(X_{5}\right)\end{array}$} & \multirow{4}{*}{$\begin{array}{l}\text { Orang-orang yang terlibat } \\
\text { langsung dalam menjalankan } \\
\text { segala aktivitas perusahaan } \\
\text { yang berhubungan dengan } \\
\text { nasabah }\end{array}$} & Penampilan petugas & Tingkat daya tarik petugas & Ordinal \\
\hline & & & Keramahan petugas & Tingkat keramahan petugas & Ordinal \\
\hline & & & Kemampuan kecepatan pelayanan & $\begin{array}{l}\text { Tingkat kemampuan } \\
\text { kecepatan }\end{array}$ & Ordinal \\
\hline & & & Kepedulian petugas & $\begin{array}{l}\text { Tingkat ketanggapan terhadap } \\
\text { keluhan nasabah }\end{array}$ & Ordinal \\
\hline & \multirow{3}{*}{$\begin{array}{l}\text { Bukti Fisik } \\
\text { (Physical } \\
\text { Evidence) } \\
\left(X_{6}\right)\end{array}$} & \multirow{3}{*}{$\begin{array}{l}\text { Merupakan suatu hal yang secara } \\
\text { nyata turut mempengaruhi } \\
\text { keputusan nasabah untuk } \\
\text { menggunakan produk jasa yang } \\
\text { ditawarkan }\end{array}$} & Kondisi kantor pelayanan & $\begin{array}{l}\text { Tingkat kelengkapan, } \\
\text { keindahan, kebersihan, dan } \\
\text { kenyamanan sarana }\end{array}$ & Ordinal \\
\hline & & & Formulir bagi calon nasabah & Tingkat kemudahan pengisian & Ordinal \\
\hline & & & Formulir pembayaran & TingkatKelengkapan Informasi & Ordinal \\
\hline \multirow{5}{*}{$\begin{array}{c}\mathrm{N} \\
\mathrm{A} \\
\mathrm{L} \\
\left(X^{\prime \prime}\right)\end{array}$} & \multirow{5}{*}{$\begin{array}{l}\text { Proses } \\
\text { (Process) } \\
\left(\mathrm{X}_{7}\right)\end{array}$} & \multirow{5}{*}{$\begin{array}{l}\text { Suatu upaya perusahaan dalam } \\
\text { melaksanakan aktivitas } \\
\text { usahanya untuk memuaskan } \\
\text { nasabah }\end{array}$} & Prosedur penyetoran dana & Tingkat kemudahan prosedur & Ordinal \\
\hline & & & Prosedur penarikan dana & $\begin{array}{l}\text { Tingkat kemudahan } \\
\text { penarikan dana }\end{array}$ & Ordinal \\
\hline & & & Kemudahan over booking & Tingkat kemudahan & Ordinal \\
\hline & & & Pelayanan on-line & Tingkat kemudahan & Ordinal \\
\hline & & & $\begin{array}{l}\text { Pelayanan menjadi nasabah } \\
\text { baru }\end{array}$ & Tingkat kesederhanaan & Ordinal \\
\hline \multirow{4}{*}{\multicolumn{2}{|c|}{$\begin{array}{l}\text { Loyalitas } \\
\text { (Loyalty) } \\
(Y)\end{array}$}} & \multirow{4}{*}{$\begin{array}{l}\text { Pembelian rutin yang } \\
\text { didasarkan pada unit } \\
\text { pengambilan keputusan }\end{array}$} & $\begin{array}{l}\text { Pembelian ulang secara } \\
\text { teratur }\end{array}$ & $\begin{array}{l}\text { Frekuensi penggunaan } \\
\text { jasa tabungan }\end{array}$ & Ordinal \\
\hline & & & $\begin{array}{l}\text { Penolakan terhadap produk } \\
\text { bank pesaing }\end{array}$ & $\begin{array}{l}\text { Tingkat penolakan } \\
\text { nasabah terhadap jasa } \\
\text { tabungan pesaing }\end{array}$ & Ordinal \\
\hline & & & $\begin{array}{l}\text { Tidak terpengaruh oleh daya tarik } \\
\text { produk pesaing }\end{array}$ & $\begin{array}{l}\text { Tingkat kekuatan nasabah } \\
\text { atas jasa tabungan pesaing }\end{array}$ & Ordinal \\
\hline & & & Penciptaan prospek & $\begin{array}{l}\text { Frekuensi merekomendasikan } \\
\text { kepada orang lain untuk } \\
\text { menjadi nasabah Bank BCA }\end{array}$ & Ordinal \\
\hline
\end{tabular}

Sumber: Berdasarkan Berbagai Referensi 


\subsubsection{Metode Penarikan Sampel}

Dalam penelitian ini ukuran sampel ditentukan oleh bentuk uji statistik yang akan digunakan. Uji statistik yang digunakan adalah analisis jalur (path analysis), di mana koefisien jalur pada dasarnya adalah koefisien korelasi. Dengan demikian ukuran sampel minimal untuk analisis jalur ini, dapat ditentukan melalui rumus ukuran sampel minimal untuk koefisien korelasi yang dilakukan secara iteratif. Dengan mengambil parameter $\rho$ (koefisien korelasi terkecil) sebesar 0,3 serta $\alpha=0,05$ dan $\beta$ $=0,05$, yang berarti $Z_{1-\alpha}=1,645$ dan $Z_{1-\beta}=$ 1,645 maka diperoleh ukuran sampel minimum 115,98 atau sebesar 116 .

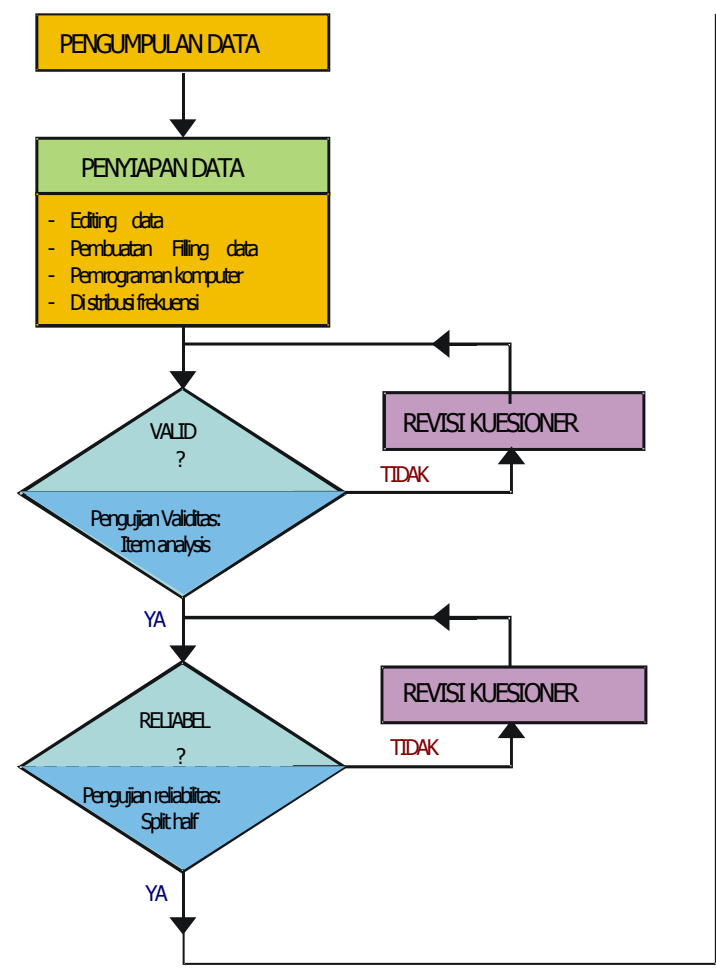

Gambar 3

Proses Analisis Data

\subsubsection{Prosedur Pengumpulan Data}

Pengumpulan data yang dilakukan penulis menggunakan teknik sebagai berikut.

1. Wawancara,

2. Kuesioner,

3. Observasi,

4. Studi kepustakaan untuk mengumpulkan data sekunder.

\subsubsection{Metode Analisis}

Secara lengkap proses analisis dapat dituangkan dalam bentuk diagram alur (flow chart) seperti pada Gambar 3 di bawah ini.

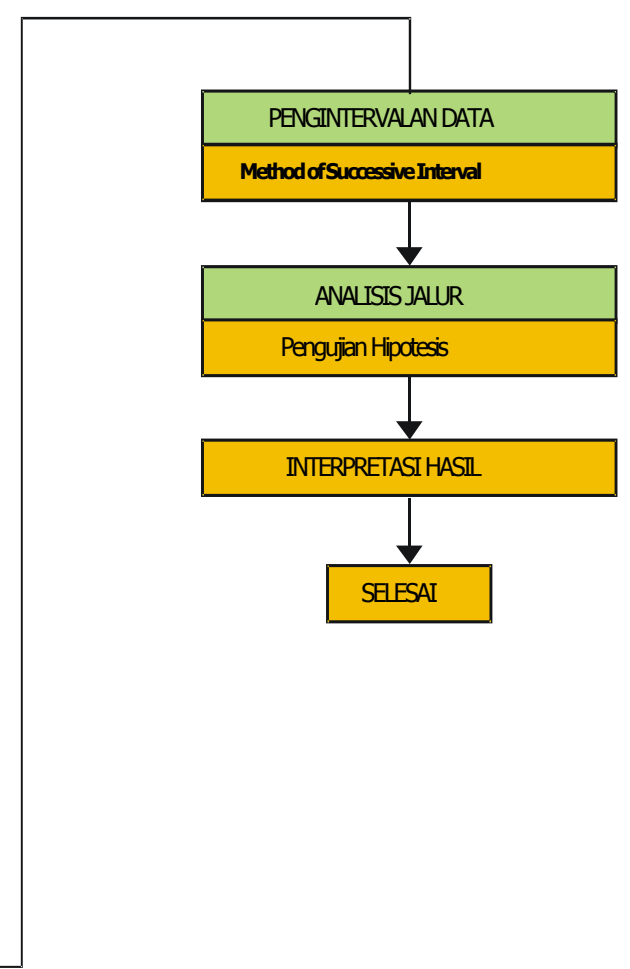

\subsubsection{Analisis Jalur (Path Analysis)}

Analisis ini digunakan untuk menentukan berapa besar pengaruh suatu variabel terhadap variabel lainnya, baik pengaruh langsung maupun tidak langsung. Besarnya pengaruh dari suatu variabel penyebab (independen) terhadap variabel akibat (dependen) disebut koefisien jalur $\left(P_{\mathrm{yx}}\right)$.
Sebelum mengambil kesimpulan mengenai hubungan kausal dalam jalur, maka terlebih dahulu diuji keberartian (signifikansi) untuk setiap koefisien jalur yang telah dihitung.

\section{(1) Koefisien Jalur Untuk Hipotesis I}




\section{StrategiC}

Hubungan kausal antarvariabel untuk hipotesis

selanjutnya.

I dapat dilihat pada Gambar 2.2 di halaman

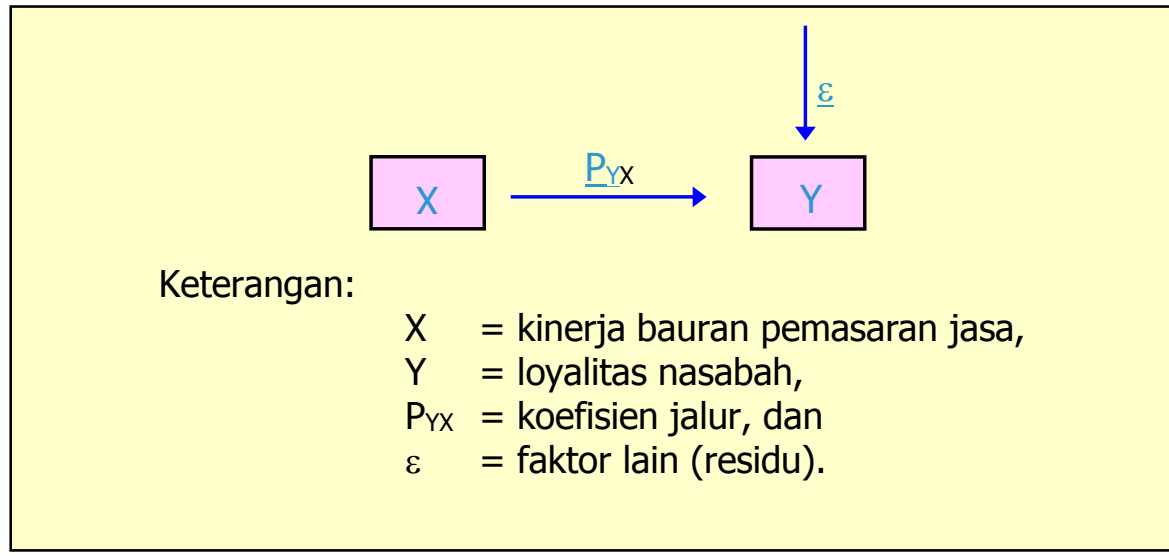

Gambar 4

Hubungan Kausal Antara Variabel $X$ dengan $Y$

Berdasarkan paradigma pada Gambar 2 terlihat bahwa hubungan antar variabel berbentuk regresi linear sederhana sebagai berikut.

$$
Y=f(X \text { dan } \varepsilon) \text { atau } Y=P_{Y X} X+\varepsilon
$$

(2) Koefisien Jalur Untuk Hipotesis II Hubungan kausal antarvariabel untuk hipotesis II dapat dilihat pada Gambar 5 berikut ini.

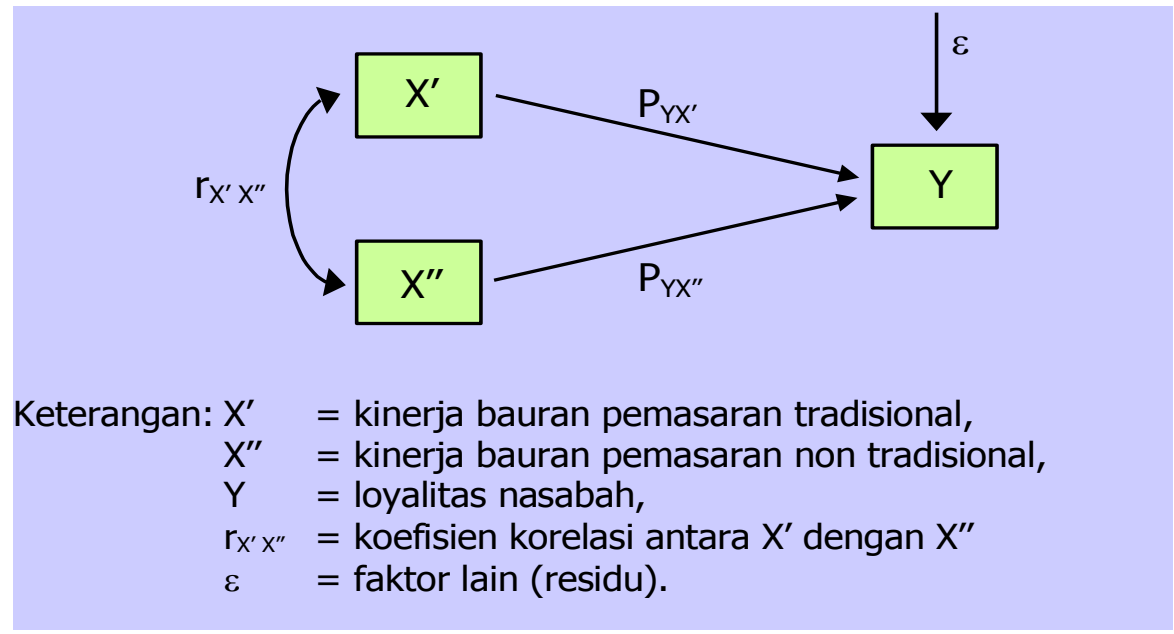

Gambar 5

Hubungan Kausal Antara Variabel X' dan X' dengan Y

Berdasarkan paradigma pada Gambar 5 terlihat bahwa hubungan antar variabel berbentuk regresi multipel sebagai berikut.

atau

$$
Y=f\left(X^{\prime}, X^{\prime \prime}, \text { dan } \varepsilon\right) \text {, }
$$

$$
Y=P_{Y X} X^{\prime}+P_{Y X^{\prime \prime}} X^{\prime \prime}+\varepsilon
$$

(3) Koefisien Jalur Untuk Hiporesis III Hubungan kausal antarvariabel untuk hipotesis III dapat dilihat pada Gambar 6 di halaman selanjutnya. 


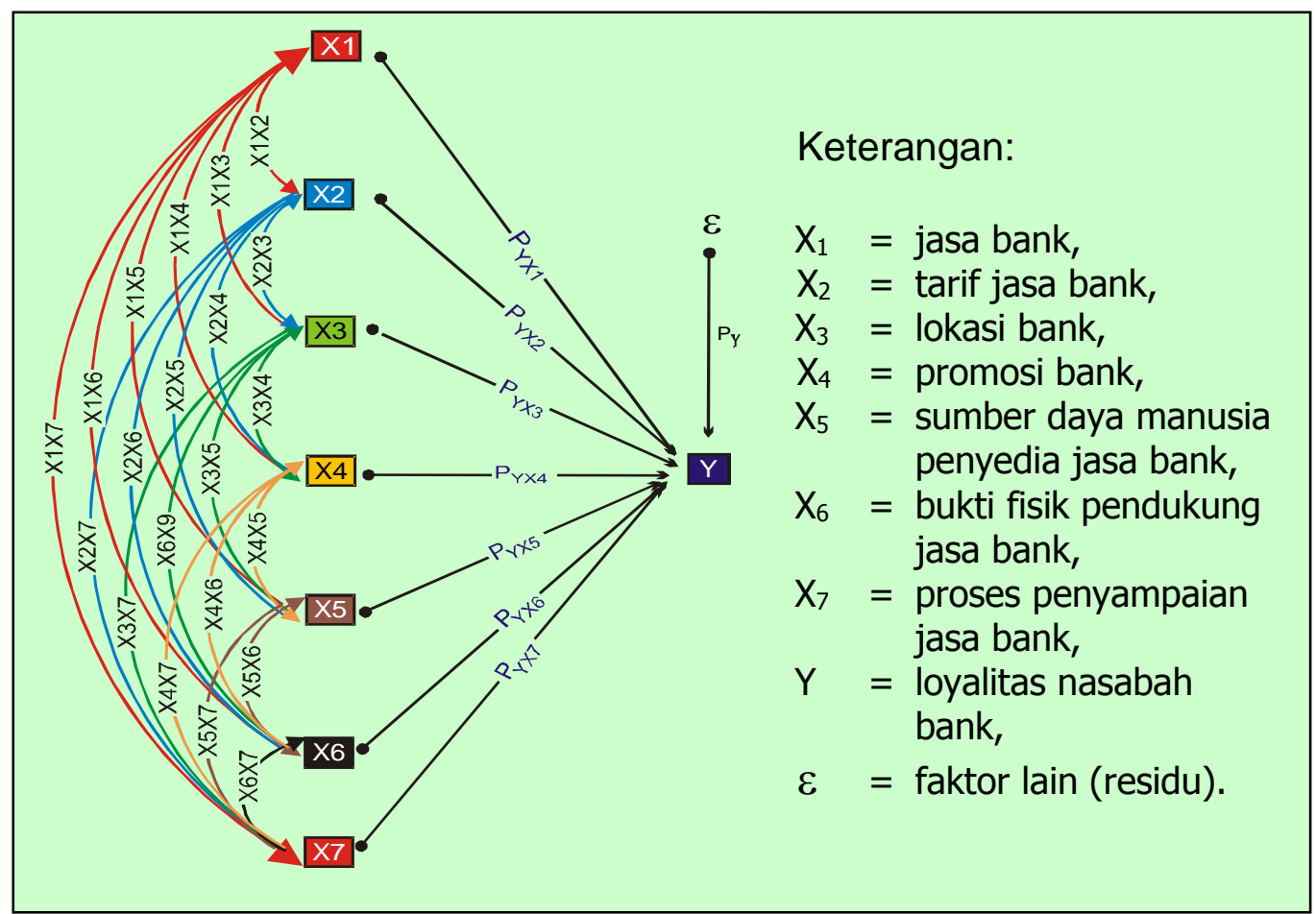

Gambar 6

Hubungan Kausal Antara Variabel $X_{1}, \ldots X_{7}$ dengan $Y$

Berdasarkan paradigma pada Gambar 6 struktur hubungan variabel tersebut dapat dinyatakan ke dalam persamaan regresi, yaitu:

$$
\hat{\mathrm{Y}}=\mathrm{b}_{0}+\mathrm{b}_{\mathrm{XY}_{1}} \mathrm{X}_{1}+\ldots+\mathrm{b}_{\mathrm{YX}_{1}} \mathrm{X}_{7}+\varepsilon
$$

IV. HASIL PENELITIAN DAN PEMBAHASAN

4.1 Pemetaan untuk Bauran Pemasaran Tradisional dan Non-tradisional

Skor rata-rata tingkat kepentingan dan kinerja bauran pemasaran baik untuk tradisional maupun non-tradisional dapat dilihat pada Tabel 2.

Tabel 2

Skor Rata-rata Tingkat Kepentingan dan Kinerja Bauran Pemasaran Tradisional dengan Non-Tradisional

\begin{tabular}{|c|c|c|}
\hline $\begin{array}{c}\text { Bauran } \\
\text { Pemasaran Jasa BCA }\end{array}$ & $\begin{array}{c}\text { Tingkat } \\
\text { Kepentingan }\end{array}$ & Kinerja \\
\hline $\begin{array}{c}X^{\prime}: \\
\text { Tradisional }\end{array}$ & 4,26 & 3,73 \\
\hline $\begin{array}{c}X^{\prime \prime}: \\
\text { Non-tradisional }\end{array}$ & 4,52 & 3,98 \\
\hline $\begin{array}{c}\text { X }: \\
\text { Total }\end{array}$ & 4,39 & 3,86 \\
\hline
\end{tabular}

Sumber : Data diolah dari kuesioner

Berdasarkan data pada Tabel 2 di atas hubungan tingkat kepentingan dengan kinerja bauran pemasaran tradisional dan non-tradisional
BCA cabang Soekarno-Hatta digambarkan dalam diagram kartesius pada Gambar 7 di halaman selanjutnya. 


\section{StrategiC}

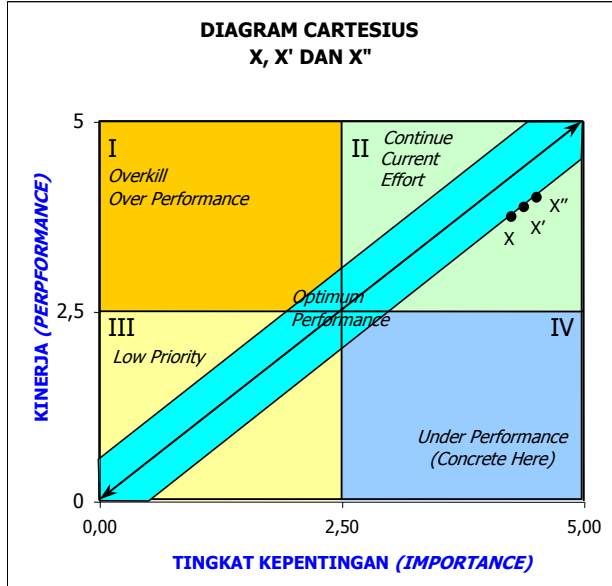

Gambar 7

Diagram Kartesius Tingkat Kepentingan dan Kinerja Bauran Pemasaran Tradisional dan Non-Tradisional BCA Cabang Soekarno-Hatta

\subsection{Pemetaan untuk Unsur-unsur Bauran Pemasaran Jasa}

Skor rata-rata tingkat kepentingan dan kinerja unsur-unsur bauran pemasaran jasa dapat dilihat pada Tabel 3.2.
Berdasarkan data pada Tabel 3 hubungan tingkat kepentingan dengan kinerja unsur-unsur bauran pemasaran jasa BCA Soekarno-Hatta digambarkan dalam diagram kartesius pada Gambar 8.

Tabel 3

Skor rata-rata kepentingan dan kinerja unsur-unsur bauran pemasaran jasa

\begin{tabular}{|c|c|c|c|c|}
\hline $\begin{array}{c}\text { Bauran pemasaran } \\
\text { Jasa BCA }\end{array}$ & $\begin{array}{l}\text { Total skor } \\
\text { Tingkat } \\
\text { Kepentingan }\end{array}$ & $\begin{array}{c}\text { Total skor } \\
\text { Tingkat } \\
\text { Kinerja }\end{array}$ & $\begin{array}{c}\text { skor rata-rata } \\
\text { tingkat } \\
\text { kepentingan }\end{array}$ & $\begin{array}{c}\text { Skor Rata-Rata } \\
\text { Tingkat } \\
\text { Kinerja }\end{array}$ \\
\hline $\mathrm{X}_{1}$ : Produk Tabungan & 2018 & 1716 & 4,35 & 3,70 \\
\hline $\mathrm{X}_{2}$ : Biaya Tabungan & 1916 & 1720 & 4,13 & 3,71 \\
\hline $\mathrm{X}_{3} \quad$ : Lokasi Bank & 1629 & 1342 & 4,68 & 3,86 \\
\hline $\mathrm{X}_{4}$ : Promosi Jasa Bank & 2839 & 2584 & 4,08 & 3,71 \\
\hline $\mathrm{X}_{5}$ : Kemampuan SDM & 2180 & 1778 & 4,70 & 3,83 \\
\hline $\mathrm{X}_{6}$ : Bukti Fisik & 4113 & 3792 & 4,43 & 4,09 \\
\hline $\mathrm{X}_{7}$ : Proses & 2625 & 2288 & 4,53 & 3,94 \\
\hline $\mathrm{X}$ : Total & 17320 & 15220 & 4,39 & 3,86 \\
\hline
\end{tabular}

Sumber : Data diolah dari kuesioner

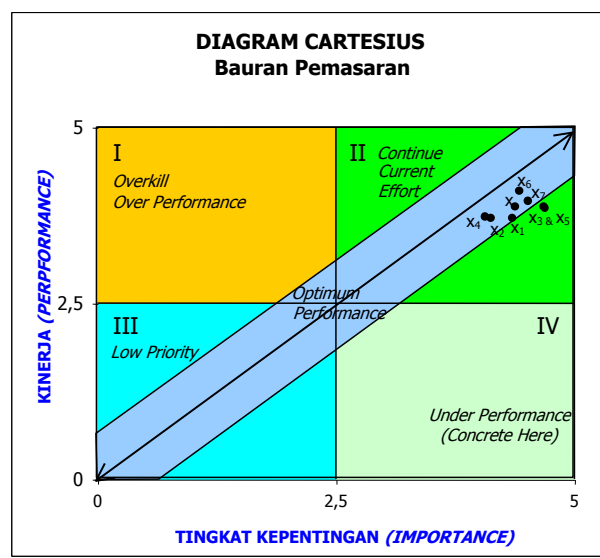

Gambar 8

Diagram Kartesius Tingkat Kepentingan dan Kinerja Unsur-Unsur

Bauran Pemasaran Jasa BCA Cabang Soekarno-Hatta 


\section{StrategiC}

4.3 Analisis Loyalitas Nasabah pada Bank Central Asia Cabang Soekarno-Hatta Bandung
Berdasarkan uraian tingkat loyalitas nasabah (responden) di atas maka dapat dikelompokan loyalitas konsumen (responden) sebagai berikut.

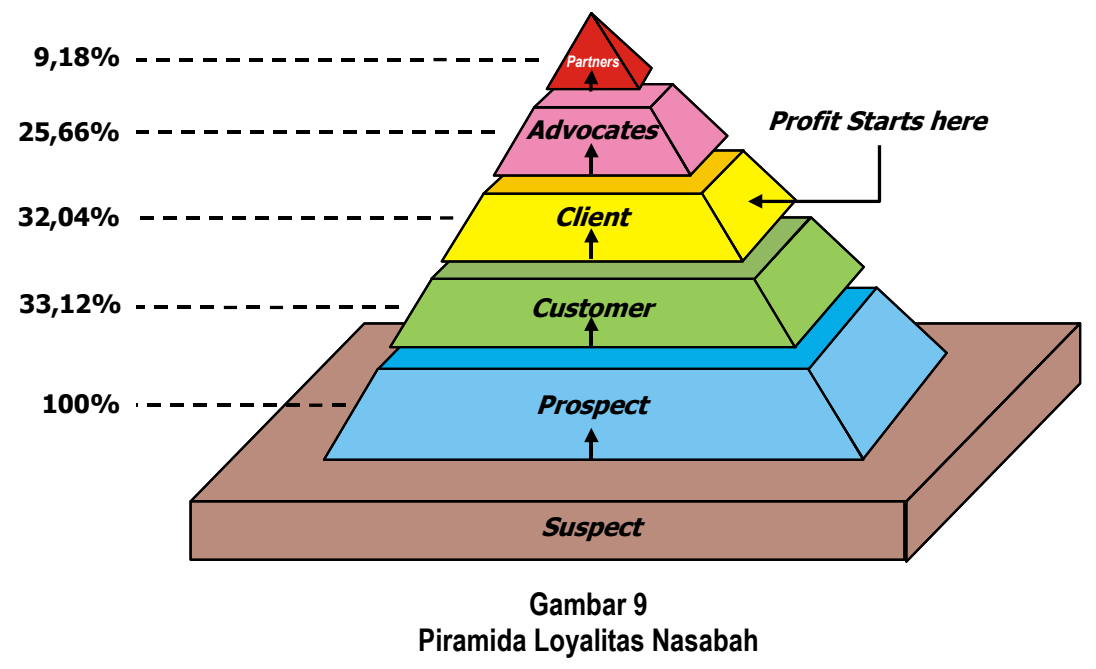

4.4 Pengaruh Kinerja Bauran Pemasaran Jasa BCA terhadap Loyalitas Nasabah

4.4.1 Korelasi Bauran Pemasaran Terhadap Loyalitas Nasabah
Dengan bantuan Software SPSS for Windows Release 10.0.1 diperoleh hasil pada Tabel 4 berikut ini.

Tabel 4

Correlations

\begin{tabular}{|ll|r|r|}
\hline & & $\mathrm{X}$ & \multicolumn{1}{|c|}{$\mathrm{Y}$} \\
\hline $\mathrm{X}$ & Pearson Correlation & 1.000 & $.890^{\star}$ \\
& Sig. (2-tailed) &. & .000 \\
& $\mathrm{~N}$ & 116 & 116 \\
\hline $\mathrm{Y}$ & Pearson Correlation & $.890^{\star *}$ & 1.000 \\
& Sig. (2-tailed) & .000 & $\cdot$ \\
& $\mathrm{N}$ & 116 & 116 \\
\hline
\end{tabular}

**. Correlation is significant at the 0.01 level

Dari perhitungan dapat dilihat bahwa korelasi antara kinerja bauran pemasaran jasa dengan loyalitas nasabah $=0,890$; dan $p$-value $=0,000$.

Karena $\mathrm{p}$-value $<0,05$ maka $\mathrm{H}_{0}$ ditolak. Artinya terdapat hubungan kausal antara kinerja bauran pemasaran jasa dengan loyalitas nasabah sehingga perhitungan dapat dilanjutkan dengan analisis jalur (path analisys).

\subsubsection{Pengaruh Kinerja Bauran Pemasaran Tradisional dan Kinerja Bauran Pemasaran Non-Tradisional terhadap Loyalitas Nasabah}

Untuk perhitungan analisis jalur, langkah pertama adalah menghitung korelasi antarvariabel. Dengan bantuan software minitab release 11.12, diperoleh hasil pada Tabel 5

Tabel 5

Pengaruh Variabel $\mathrm{X}$ terhadap Variabel $\mathrm{Y}$ secara Proporsional

\begin{tabular}{|c|c|c|c|c|}
\hline \multirow{2}{*}{ Variabel } & \multirow{2}{*}{ Pengaruh Langsung } & \multicolumn{2}{|c|}{ Pengaruh Melalui } & \multirow{2}{*}{ Pengaruh Total } \\
\cline { 3 - 5 } & & $X^{\prime}$ & $X^{\prime \prime}$ & \\
\hline X' $^{\prime}$ & 0.2285 & - & 0.1684 & 0.3969 \\
\hline X' & 0.2280 & 0.1684 & - & 0.3964 \\
\hline
\end{tabular}

Sumber: Berdasarkan Hasil Pengolahan Data 


\section{StrategiC}

Jika dibandingkan pengaruh bauran pemasaran non-tradisional dan tradisional terhadap loyalitas nasabah di BCA Soekarno-Hatta ternyata pengaruh bauran pemasaran tradisional sedikit lebih besar dari pengaruh bauran pemasaran non- tradisional (Gambar 10). Hal ini relevan mengingat perbankan merupakan industri high level of customer contact with service organizations dengan emphasizes encounters with equipment (Lovelock, 2002:53).

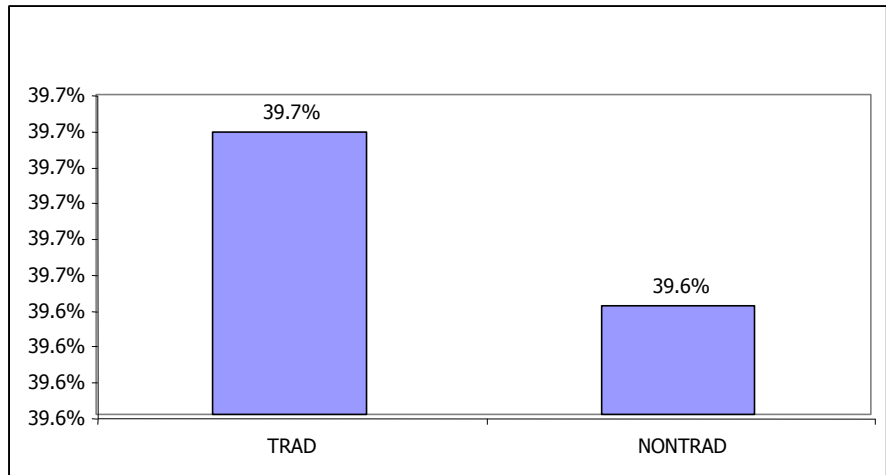

Gambar 10

Grafik Pengaruh Variabel X' dan X' terhadap Y

Apabila dilihat unsur-unsur bauran pemasaran tradisional, yang paling besar pengaruhnya terhadap loyalitas nasabah adalah promosi (promotion) sedangkan untuk bauran pemasaran non-tradisional yang paling besar berpengaruhnya adalah bukti fisik (physical evidence). Secara lengkap pengaruh unsur-unsur tersebut dapat dilihat pada Tabel 6 dan Tabel 7 di bawah ini.

Tabel 6

Pengaruh Bauran Pemasaran Tradisional

\begin{tabular}{|l|c|}
\hline \multicolumn{1}{c|}{ Variabel } & Pengaruh \\
\hline$X_{4}:$ Promosi Bank & $24.72 \%$ \\
\hline$X_{3}:$ Lokasi Bank & $17.37 \%$ \\
\hline$X_{2}:$ Tarif Jasa Bank & $16.26 \%$ \\
\hline$X_{1}:$ Jasa Bank & $11.11 \%$ \\
\hline
\end{tabular}

Sumber: Berdasarkan Hasil Pengolahan Data

Tabel 7

Pengaruh Bauran Pemasaran Non-Tradisional

\begin{tabular}{|l|c|}
\hline \multicolumn{1}{|c|}{ Variabel } & Pengaruh \\
\hline$X_{6}:$ Bukti Fisik Pendukung Jasa Bank & $26.76 \%$ \\
\hline$X_{7}:$ Proses Penyampaian Jasa Bank & $25.43 \%$ \\
\hline$X_{5}:$ Sumber Daya Manusia Penyedia Jasa Bank & $17.18 \%$ \\
\hline
\end{tabular}

Sumber: Berdasarkan Hasil Pengolahan Data

\subsubsection{Pengaruh Kinerja Unsur-unsur Bauran Pemasaran Jasa BCA Soekarno-Hatta Bandung Terhadap Loyalitas Nasabah}

Pengaruh unsur bauran pemasaran yang paling besar terhadap loyalitas nasabah di BCA
Soekarno-Hatta Bandung adalah bukti fisik $\left(X_{6}\right)$. Secara lengkap unsur-unsur bauran pemasaran yang berpengaruh kepada loyalitas nasabah dapat dilihat pada grafik seperti Gambar 11 di halaman selanjutnya. 


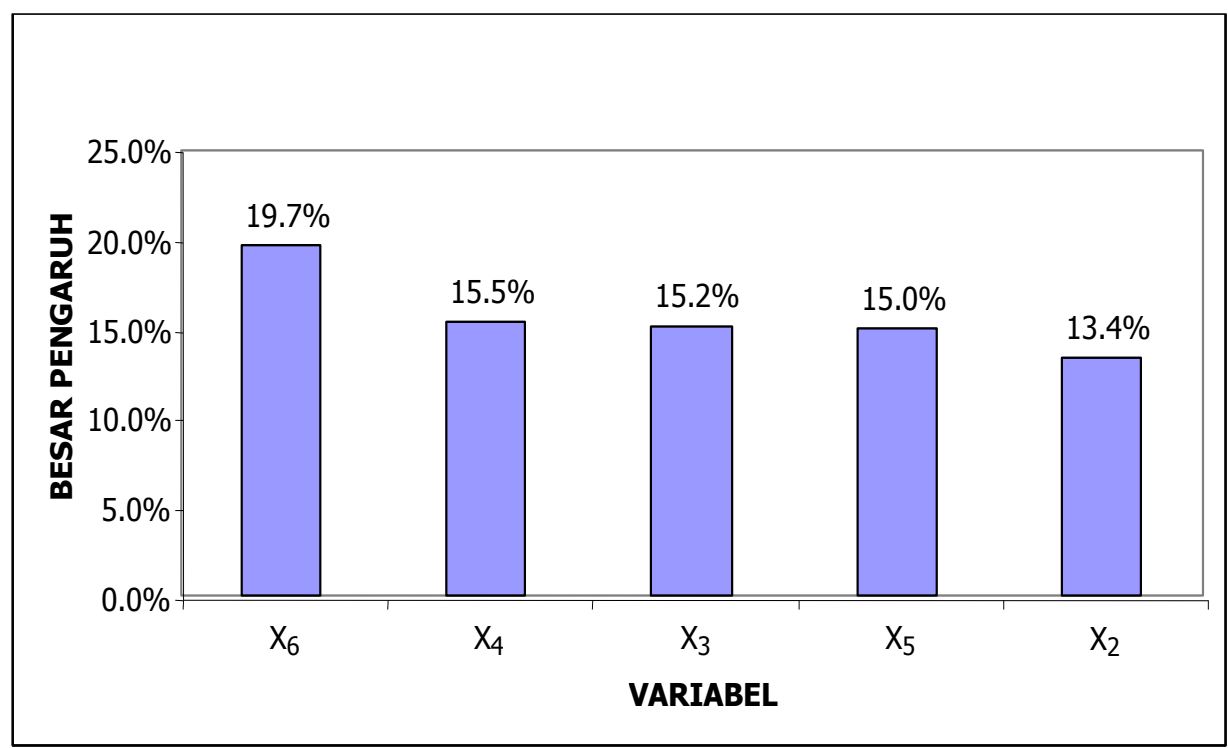

Gambar 11

Grafik Pengaruh Variabel $X$ terhadap $Y$

\section{KESIMPULAN}

Berdasarkan hasil penelitian yang dilakukan di BCA Soekarno-Hatta Bandung, diperoleh beberapa simpulan sebagai berikut.

1. Bauran pemasaran tradisional, bauran pemasaran non-tradisional, serta bauran pemasaran secara total sudah terletak di daerah optimum meskipun belum terletak pada garis diagonal. Hal ini menunjukkan bahwa kinerja bauran pemasaran BCA Soekarno-Hatta sudah termasuk optimum.

2. Bauran pemasaran tradisional, bauran pemasaran non-tradisional, serta bauran pemasaran secara total terletak di kuadran II dari performance-importance mapping. Hal ini menunjukkan bahwa apa yang telah dilakukan selama ini harus dipertahankan (continue current effort) dan ditingkatkan karena hal-hal yang dianggap penting dan sangat penting oleh nasabah telah memberikan kinerja yang baik pula dirasakan oleh nasabah.

3. Meskipun secara total kinerja bauran pemasaran jasa sudah optimum, ada dua unsur yaitu lokasi dan SDM/petugas yang masih kurang optimum sehingga perlu peningkatan kinerja BCA Soekarno-Hatta Bandung untuk kedua unsur tersebut.

4. Tingkat loyalitas nasabah BCA Cabang Soekarno-Hatta Bandung relatif tinggi, karena mayoritas pelanggan $(66,88 \%)$ sudah merupakan kelompok yang memberikan kontribusi keuntungan (profit) bagi perusahaan, yaitu clients, advocates, dan partners.

5. Kinerja bauran pemasaran jasa, baik bauran pemasaran tradisional maupun bauran pemasaran non-tradisional secara sendiri-sendiri dan secara bersama-sama sangat berpengaruh terhadap loyalitas nasabah penabung BCA Soekarno-Hatta Bandung.

6. Pengaruh kinerja bauran pemasaran tradisional sedikit lebih besar dari pengaruh kinerja bauran pemasaran non-tradisional terhadap loyalitas nasabah penabung di BCA Soekarno-Hatta Bandung.

7. Pengaruh terbesar dari ketujuh unsur-unsur bauran pemasaran jasa adalah bukti fisik (physical evidence), sedangkan produk dan proses tidak berpengaruh terhadap loyalitas nasabah BCA Soekarno-Hatta Bandung.

\section{DAFTAR PUSTAKA}

Donnelly, James, H, JR. 1974. Distributing Bank Services dalam Marketing for The Bank Executives. New York: Petrocelli Books.

Griffin, Jill. 1997. Customer Loyalty: How to Earn It, How to Keep It. Second Ed.. New York: Lexington Books, 
Hill, Nigel. 1996. Handbook of Customer Satisfaction Measurement. First Ed. Hampshire: Gower Publishing Limited.

Kotler, Philip and Gary Amstrong. 1996. Principles of Marketing. Seventh Ed.. New Jersey: Prentice Hall Inc.

Kotler, Philip. 2000. Marketing Management: Analysis, Planning, Implementation and Control. The Millenium Edition. Englewood Cliffs, Nj07632: Prentice Hall International Inc, A. Division of Simon \& Scuster.

Kurtz, David and E. Clow Kenneth. 1998. Service Marketing. Prentice Hall International Inc.

Lovelock, Christopher, H and Wright Lauren. 2002. Principles of Services Marketing and Management. Second Ed.. New Jersey: Prentice Hall International Inc.

Roland, Rust T., Anthony J. Zahorik, Timothy L. Keiningham. 1996. Service Marketing. Harper Collins College Punlishers.

Rust, Roland T, Zahorik, Anthony J, Keiningham, Timothy L. 1996. Service Marketing. First Ed., New York: Harper Collins College Publishers.

Stanton, William J. \& Charles Futrel. 1994. Fundamental of Marketing. $8^{\text {th }}$ Edition, Singapore: Mc. Graw Hill.

Tjiptono, Fandy. 1998. Manajemen Jasa. Edisi Pertama. Yogyakarta: Andi Offset,

Zeithaml, Valarie A, Mary Jo Bitner. 2000. Services Marketing. International Ed.. Singapore: Mc Graw Hill, Inc..

Research/Report

Mc Kinsey, and Co. 2000. "Personal Finance

Service Research", Jakarta: EIU, Viewswire, 